\title{
Theofilos
}

A Nordic open access journal in Theology, Philosophy and Culture

Published by NLA University College - in partnership with Johannelund School of Theology

Available at www.theofilos.no

\section{The Apologetic Fruitfulness of a Revised Natural Theology}

\author{
Knut-Willy Sather \\ Professor at Department of Religious Studies \\ Volda University College \\ knut-willy.saether@hivolda.no
}

\begin{abstract}
This article explores the epistemological locus of a revised natural theology (RNT) and examines the apologetic fruitfulness of this concept. In the current science-religion dialogue, RNT is advocated by scholars such as John Polkinghorne. I argue in this article that RNT partakes of the nature of faith and can be labelled as theological metaphysics. The apologetic output is then mainly seen as a contribution to constructing a coherent philosophical-theological understanding of reality. For being able to do this, we need to acknowledge a wider epistemological framework for RNT. One step is to rephrase the underlying critical realism to a constructive critical realism. This approach takes better into account the complexity of our reality. Thus, the apologetic fruitfulness can be evaluated against other competitive coherent systems at a transdisciplinary level.
\end{abstract}

Keywords: Revised natural theology, theological metaphysics, constructive critical realism, fideism, foundationalism, coherentism

\section{Introduction}

I $n$ this article, I will problematize the locus of a revised natural theology (RNT) and examine the apologetic fruitfulness of this concept. In the current science-religion dialogue, scholars such as John Polkinghorne argues for RNT. ${ }^{1}$ Such natural theology starts with insight from the scientific endeavor and elaborates this insight into a larger picture of reality. It differs from the old fashion natural theology in several ways. It is more modest, talking about hints and signs, instead of proofs and evidence. It does not emphasize any particular scientific insight but looks at the ground of all science's explanation. The content of a revised natural theology according to Polkinghorne can be summarized is three topics: (1) The intelligibility of nature (2) The fine-tuning of nature (3) The beauty of nature. ${ }^{2}$

By apologetic fruitfulness, I have in mind how RNT tries to make Christian faith reasonable, understandable, and communicable. Polkinghorne uses the phrase 'motivated belief' for his point of departure, and his approach is a mediation on the relationship between science and theology. Such an apologetics also offers an open-minded and critical attitude towards both science and theology that constitutes an insightful case for the truth of Christian faith.

By searching for the locus of RNT, I have in mind how RNT fits into a larger epistemological picture. Such a picture includes both a discussion of what kind of theology RNT is, and a clarification of 
how we can understand RNT in a broader picture of knowledge, including how RNT relates to topics such as critical realism, foundationalism, and coherentism.

I will not map out the specific content of RNT, as this is done elsewhere. ${ }^{3} \mathrm{My}$ agenda is to problematize the RNT itself as a package of thinking. My sub-questions concerning the locus of RNT are twofold: (1) What kind of theology are we dealing with in RNT? (2) How does RNT fit into a larger epistemological picture of our knowledge? Having explored these two questions, I finally address the apologetic fruitfulness of this type of natural theology.

\section{Revised natural theology - what kind of theology?}

RNT is obviously about doing some sort of theology. In my context, I am not searching for particular theologies in the sense as different dogmatic systems or denominational traditions. The clarification of theology I am doing here is, in one sense, more fundamental, by unpacking theology as a field in an interdisciplinary context, namely the science-religion debate. Polkinghorne is relevant for this purpose. He differentiates between systematic theology and metaphysical theology. Systematic theology is: 'the specialist investigation of particular types of experience and insight which we label religious.' 4 This type of theology is comparable with other rational discourses and has a starting point in its own data, namely Scripture, tradition, and reason. Doing this type of theology - labelled as first-order theology - requires an openness and has to be 'prepared to conform to the discovered nature of reality and not shackled by prior prescription of what are the acceptable outcomes of the enquiry.' 5 In Polkinghorne's terms this is doing theology 'bot- tom-up'.

Theological metaphysics, on the other hand, is understood as the great synthesizing discipline which includes first-order rational discourses. Theological metaphysics can be described as a rational discourse with at least one assumption: God's existence. Polkinghorne says theological metaphysics has a starting point in a fundamental principle: belief in God as the ground of being. This kind of theology is also labelled philosophical theology or second-order theology. Theological metaphysics is informed by insight from first-order theology, as well as other fields. When doing theological metaphysics, we try to bring different first-order results (from both science and theology) together and on this basis search for a consistent and coherent picture of the world. ${ }^{6}$ This can be described as the active role of theological metaphysics. In addition, we find a passive role, as theological metaphysics ought to respect different fields which it is informed by. Thus, theological metaphysics tries to stay clear of instructing or correcting specific firstorder insight, such as insight form natural sciences.

It is not directly clear in Polkinghorne's writings what sort of theology RNT is. However, he says RNT partakes of the nature of faith, and I have argued elsewhere for locating RNT to the campus of theological metaphysics. ${ }^{7}$ I find three reasons for this. First, natural theology has always looked closely at what the sciences have been saying about the world, this is also the case for RNT. However, to look closely, is not to relate itself to science in such a way as 'finding God's finger' or filling the 'gaps' with God as an explanation. Hence, RNT tries to avoid the failure of God-of-the-gaps. RNT does not deal with particular occurrences in nature, 
but with the whole ground of the scientific endeavor. Hence, RNT is informed by theories from natural science without overruling them.

Second, the content of RNT (the intelligibility of nature, fine-tuning of nature, and the beauty of nature) is not results from science as data or theories. The insight arises out of the scientific endeavor, but are not explainable within science. This is not God-of-the-gaps, as it is not an attempt to provide theological answers to scientific questions. RNT emphasizes that science seems: 'to throw up questions which point beyond itself and transcend its power to answer.'8 Thus, RNT is a trans-disciplinary interpretation of topics developing from science.

Third, we should not have too strong ambitions concerning what we conclude from such an insight. What we can do, is to be informed by natural science, and bring the insight into a larger interpretive philosophical framework (that is theological metaphysics). From this, RNT cannot claim any universal certainty, as it at least has one assumption: It partakes of the nature of faith in God. Therefore, RNT as a transdisciplinary interpretation does not advocate 'knock down' arguments but strives for a coherent picture if the world.

Such a larger interpretive philosophical framework corresponds with Niels Henrik Gregersen. He argues that the science-religion dialogue is an interdisciplinary dialogue which takes place as a transdisciplinary interpretation of the methods and results from different fields and always involves philosophical questions. ${ }^{9}$ The role of theology of this type, as theological metaphysics, is as an integrative discipline, bringing together insight from different fields into a larger picture. ${ }^{10}$
Thus, in Polkinghorne's concept RNT works as a core link between science and theology, or more precisely: between natural science and theological metaphysics. However, for being able to analyze further such a link, with relevance for how to understand RNT's apologetic fruitfulness, we need to explore the underlying epistemological framework of this type of natural theology. This framework is critical realism. In short, we can say that a critical realistic epistemology makes RNT possible.

\section{Revised natural theology and critical realism}

Critical realism, even limited to the science-religion debate, is a comprehensive topic. ${ }^{11}$ I will not delve deeply into this but clarify a few points with relevance for RNT. In general, critical realism consists of an ontological claim (realism) and an epistemological claim (critical). We need to be aware that critical realism spans over many different approaches, so we actually deal with various critical realisms. My point here is not to analyze varieties of critical realism but problematize the overall position as such in the context of the science and religion debate.

Critical realism in science is not so much a questioned topic; it is critical realism in theology which has been heavily debated.12 Polkinghorne as a critical realist has been criticized for doing a shortcut by taking scientific critical realism as underlying both the scientific and the theological enterprise. Critical realism, as such, has also been criticized for remaining caught in 'modernistic' structures, such as epistemological foundationalism, representational thinking with a correspondence theory of truth, and excessive individualism. ${ }^{13}$ I find the critics of the 'old fashion' critical realism in the science 
and religion dialogue partly legitimate, especially the points problematized by Kees van Kooten Niekerk. In short, he warns us against making short-cuts from critical realism in science to critical realism in theology. Some of his arguments are the following.

First, we have the problem of God as an object. We cannot experience God in the same way as we have sensory experiences in nature. Van Kooten Niekerk says:

theology differs from science in that it is contested whether its core subject matter (God) exists at all. And, of course, [this] affects the plausibility of the reality claims that are contained in theological propositions. ${ }^{14}$

Second, we have the problem that religious experience cannot be subject to testing in the same way as we do experimental testing in science. This point emphasizes the hermeneutical dimension in theology. In one sense, religious experience only exists in the past conveyed through oral or written testimonies. Hence, in these testimonies experience and interpretation are intertwined.

Third, in theology we have to deal with the metaphorical character of the religious language. We express God in metaphors, such as 'father' or 'shepherd'. Further, the metaphorical language expresses God as experienced in and through a personal relationship. Even though we use metaphors and models also in science, they are fundamentally different from what is going on in theology, van Kooten Niekerk says.

In light of these differences, he prefers to use the term 'modified critical realism' in theology. Anyway, a modified critical realism in theology can hardly be justified outside a Christian tradition, as it requi- res a positive attitude to Christian faith in the first place. Van Kooten Niekerk concludes: 'In a fundamentally way it is a question of fides quaerens intellectum (faith seeking understanding), which remains within the context of faith.' 15

Polkinghorne's critical realism does not dissolve the epistemological differences in science and theology, as he pays attention to some of the similar considerations raised by van Kooten Niekerk. However, the epistemological differences are more clearly articulated by van Kooten Niekerk. My reason for acknowledging the differences between critical realism in science and in theology is to emphasize that reality has a many-layered structure. This is not an attempt to advocate a fragmentated view of reality. It is rather the opposite: arguing for a holistic and consistent view of reality which takes into account as best as possible the complexity of the reality in which we try to understand.

My next step is therefore to emphasize more thoroughly an epistemology which pays attention to the many-layered structure of reality. Van Kooten Niekerk's considerations are a necessary first step. However, we need to elaborate this further.

In the science-religion dialogue, Andreas Losch explores a trajectory to solve the challenges with the old fashion critical realism which relies too heavily on an epistemology which is based on how natural science works. He has coined the term constructive critical realism. By doing this, he emphasizes the social and cultural dimensions in our search for knowledge. He says the original critical realism too easily weaves natural science and theology together in one epistemological package. Losch argues for a wider approach to rationality: 'the rationalities 
of natural, social, human science and of course theology are different ones...'16 There must be different rationalities since the objects for these fields are different, and our approach to the objects needs to correspond to the distinctive character of the objects.

Losch develops a broader picture compared with Polkinghorne by including a variety of fields, such as the humanities and social sciences. There are undoubtedly different rationalities involved in our search for knowledge. Losch points out that the traditional critical realism is limited since the distinctive character of different fields has not been sufficiently considered. Losch says: 'The concept of constructive-critical realism assumes that in the process of science (and in its application as well), cultural construction carrying ethical decisions is taking place. ${ }^{17}$ For Losch, our approach to knowledge and our understanding of rationality need to take the 'postmodern challenge' seriously, which in this context gives voice to the cultural and social dimensions in doing science. Thus, such a concept will acknowledge the heritage of modernity as well as the insight from our postmodern context which emphasizes the personal, social and cultural dimension of rationality.

Losch describes the 'postmodern situation' as an opening into new possibilities. He says it opens up space for a new common ground:

Our access to truth is limited; each person can know directly very little of truth and must trust others for the rest. Nevertheless, this limited access to truth represents a common ground on which we can claim freedom and respect. It provides the spiritual foundation of a free society, the achievement of which Polanyi called 'man's cosmic calling'. ${ }^{18}$
At the core of Losch's constructive-critical realism is a two-fold understanding of our search for knowledge. There is a 'constructive direction to shape the world by the use of culture toward the realization of increasing freedom and is, yet, critically aware of its limits: nature's limited resources and sin's diminishment of man's ability of recognition. ${ }^{19}$

The traditional critical realism, advocated by Polkinghorne, can be expanded and adjusted by Losch's constructive critical realism. RNT, as arguing for theism as the best explanation, can benefit from such a broader constructive critical realism. I will emphasize two points based on my analysis above. First, we are not solely 'caught' in modernism, but we relate our epistemology to the postmodern situation. This makes RNT more relevant in dialogue with the current cultural situation. Second, in RNT we do not narrow our focus to natural science and theology but rather expand our approach to include the humanities and other broader fields as well. Our reality is one, but it is many-layered in the sense that we have different approaches with their distinct methodologies in which we try to gain knowledge and insight. In Losch's word, our world is more than physics. RNT can be enlarged by embracing a wider range of fields, and not only being informed by the natural sciences.

In the extension of these two points, a third one with relevance for RNT emerges out of constructive critical realism. The constructive part opens up for a consciousness of the ethical dimension in all search for knowledge. When opening for a constructive critical realistic epistemology in the human sciences, the recognition of its ethical implications cannot be avoided, Losch says. ${ }^{20}$ Thus, our search for knowledge is intertwined with ethical 
decisions. RNT would benefit with a stronger emphasize on the ethical dimension of the purpose of our knowledge, which also has relevance for its apologetic fruitfulness.

\section{Fideism, foundationalism, and coheren- tism}

I will now turn more directly to the apologetic fruitfulness of RNT. As already mentioned, RNT has to be understood as arguing for theism as the best explanation. So far, I have mapped out that RNT is taking place within the context of theological metaphysics and is about a transdisciplinary interpretation of insight from different fields. Theological metaphysics, as well as RNT, assumes the existence of God. This gives us at least one challenge: What is the apologetic fruitfulness of arguing for a theistic belief when the arguments are interpreted beforehand within a theistic framework? Is not theological metaphysics, and then RNT, a self-supporting house of cards, confirming what we already have as assumption(s)? My questions echoes van Kooten Niekerk's observation of the underlying (modified) theological critical realism: The fact that it requires a positive attitude to Christian faith in the first place.

Since theological metaphysics and RNT has at least one assumption, God's existence, we need to clarify this in light of fideism. Broadly spoken, fideism is a position claiming that faith in God is in one sense a God-given gift, independent of reason. Thus, reason is not suited to justify religious faith. Fideism takes many shapes and colors. However, I will emphasize one point in relation to the role of RNT within the context of theological metaphysics. Starting with faith, i.e. belief in God, is something different than starting with specific given theological con- cepts which frames all other kinds of knowledge. The problem with fideism is its tendency to individualism where we all individually claim some sort of infallible information from God. The history of theology has shown us that such claims have fall short. An apologetics weaved together with fideism is not a fertile strategy.

However, theological metaphysics is not fideism. Polkinghorne argues for theological metaphysics as a legitimate taken position informed by different fields. Hence, the role of theological metaphysics is to take seriously the insight from natural science, and I will in company with Losch, include such as the humanities and social sciences. Our insight arises from available data, from testing hypothesis, and by formulating theories, and is not based on prior faith statements or dogmatic claims. My short clarification of RNT as not belonging to the campus of fideism, is partly related to another discussion concerning the structure of knowledge, namely foundationalism and coherentism.

By arguing for RNT with an underlying constructive-critical realism, I will not follow the road of foundationalism, neither the road of relativism. Foundationalism spans over a wide range of positions, and foundationalist theories differ in the kind and degree of dependence they assert, such as strong and moderate foundationalism. ${ }^{21}$ Foundationalism within the context of theology starts with some dogmas, which rely on themselves. ${ }^{22}$ Such a foundationalist view can within the context of theology be related to fideism. Foundationalism represents some obvious challenges, both from a general epistemological point of view and from a more specific theological one.

On the other hand, if we do not start 
with some givens, as in foundationalism in the general sense above, are we then lost in the sea of relativism? In contrast to foundationalism, coherentism is another strategy to structure our knowledge. This can be done without giving up some sort of correspondence to reality (the latter is a core element in critical realism). Coherentism argues that justification of a belief depends on its coherence with other beliefs that one holds. In this picture, our structure of knowledge takes shape as a net, consisting of different kinds of knowledge that in various ways are related to each other. Since such a net runs the risk for being a closed system without reference to the real world (e.g. a fictive world), we need some sort of correspondence or reference to reality. This can be solved in different ways, such as van Huyssteen's postfoundationalism and Gregersen's contextual coherence theory. ${ }^{23}$ The latter argues, by following Nicolas Rescher, for an understanding of data as not givens in the sense of truth, but as immediate truth. Thus, coherentism does not only mean an inner logical consistence between propositions, but also a systematic organization of contextual propositions grown out of experience. ${ }^{24}$ According to Gregersen, we then avoid the danger that the coherent structure is purely logical or at least intralinguistic connectives without reference to the world.

RNT with its underlying constructive critical realism can benefit as an apologetic contribution when carefully navigating between the two extremes: foundationalism caught in modernistic assumptions, and coherentism without some claims of reference to reality. However, RNT as theological metaphysics has at least one assumption or starting point (although not foundationalism), which is needed for making the whole apologetic endeavor meaningful. This assumption is at the very core of theological metaphysics itself: Belief in God.

The apologetic fruitfulness of RNT is then to argue for a coherent picture of the world on a transdisciplinary level informed by insight from different fields. The underlying epistemology finds its way as a constructive critical realism, navigating between the extremes of fideism, foundationalism and relativism. To avoid apologetics ending up as a self-supporting house of cards, or as one of many competitive coherent systems without reference, the realistic claim in constructive critical realism must be acknowledged. This is the true road of doing theological metaphysics.

Further, by striving for a coherent construction, the apologetic fruitfulness can only be evaluated against other competitive coherent systems at a transdisciplinary level. At this point, Polkinghorne gives us an illustrative closing example of comparing different coherent systems:

Firstly, you can just take the brute fact of the physical world as your starting point. That's what somebody like David Hume would take. Start with the brute fact of matter as your unexplained bases. Or secondly, you can take the brute fact (if that's the word to use) of God. In other words, one can appeal to the will of an Agent, the purpose of a Creator, as the basic unexplained starting point for understanding the world. 25

These two different approaches can be described as atheism and theism, respectively. RNT, in the realm of theological metaphysics, makes sense as apologetics in terms of arguing for Christian theism as a more coherent description of reality.

The ethical dimension conveyed from constructive critical realism is my final 
stop. We need to rethink the purpose of apologetics in light of what theology is all about. In the context of apologetics, we too often deal with theology as knowledge acquisition. Miroslav Volf and Matthew Croasmun point out that, by focusing on knowledge at large, academic theology has lost track of its normative role. According to Volf and Croasmun, the "theological knowledge building" had been done at the expense of theology's ability to address normative questions. This is part of a broader academic picture:

As scientists, theologians can talk about what is and what is likely to be, but not about what should be and what we ought to hope for in the future. This, too, is a fate theology shares with humanistic disciplines, which have also traded their ability to address the "big questions" of human life for academic respectability in an intellectual environment dominated by the sciences. ${ }^{26}$

When we reduce theology to knowledge acquisitions, Volf and Croasmun continue, we are caught by a methodological constraint, which leaves little room for practical wisdom and normative judgements. Volf and Croasmun's emphasis on the normative purpose of theology corresponds with Losch's ethical concern developed in constructive critical realism. Apologetics is not so much about arguing for Christian faith as a package of knowledge acquisitions as it is about dealing with practical wisdom, and what this life is all about. Or, to use Aristotelian terms, theology is more than episteme: it is phronesis. Thus, the fruitfulness of doing apologetics is dependent on its ability to take part in the discussion of relevant normative challenges in the public sphere. Contemporary challenges include climate change, challenges on human uniqueness, and bio-technology.

\section{Closing remarks}

According to Polkinghorne, RNT is about arguing for theism as the best explanation. The locus of RNT, as this article displays, has some advantages and challenges. As an apologetic contribution, my conclusion is that RNT needs to be clarified and developed in two ways: (1) A clearer and more thoroughly understanding of the locus of RNT as theological metaphysics (2) A more profound understanding reflecting the many-layered structure of reality, which demands different methods, approaches, and involves different fields.

If RNT is about a transdisciplinary interpretation, then RNT as such assumes the existence of God. As an apologetic contribution, the realm of theological metaphysics is about developing a coherent understanding of reality, informed by insight from different fields. RNT can never be a matter of knockdown arguments, proofs or inferences from nature to God. Belief in God is a precondition for practicing RNT. The task for RNT is to argue for, and give good reasons for, belief in God by following Anselm's phrase 'faith seeking understanding'. With RNT as a transdisciplinary interpretation, we can develop a more profound and nuanced reflection of the traditional topics, such as the intelligibility of nature, the fine-tuning of nature, and beauty of nature. ${ }^{27}$

Finally, RNT should not be solely about reasoning within the context of natural science and theology. The original RNT confine itself too much to these two. One reason for this limitation is the underlying old fashion critical realism. 
We need to extend our epistemology as well. I have argued for a wider approach, where we pay attention to insight from different fields, including the humanities and social sciences. In this respect, Losch's constructive critical realism is useful. Constructive critical realism takes the postmodern situation seriously and finds its way via media foundationalism and relativism. In addition, it emphasizes the ethical dimension in our search for knowledge. The latter is most urgent for both the topics we consider as important in our apologetic endeavor today, such as climate change and the human uniqueness, as well as the credibility for how we practice apologetics in the public sphere.

\section{Notes}

1 We find many extensive contributions to a revised natural theology, although with some variations, such as Alister E. McGrath, The Open Secret: A New Vision for Natural Theology (Malden, Blackwell, 2008) and Re-imagine Nature: The Promise of a Christian Natural Theology (Hoboken, Wiley-Blackwell, 2016). In this article, I follow the concept developed by John Polkinghorne. He is considered as first-generation scientisttheologians (together with Ian G. Barbour and Arthur. E. Peacocke), and he uses explicitly the term "revised" in his natural theology. In addition, many of those who argue for a revised natural theology is in dialogue with core elements in Polkinghorne's thinking.

2 See John Polkinghorne, One World: The Interaction of Science and Theology (London: SPCK, 1986), 45ff.

3 See Knut-Willy Sæther, Traces of God (Trondheim: Tapir Academic Press, 2011), 113ff.

4 John Polkinghorne, The Faith of a Physicist: Theological Reflections of a Bottom-up Thinker (Princeton: Princeton University Press, 1994), 46.

5 John Polkinghorne, Faith, Science and Understanding (London: SPCK, 2000), 19.

6 Polkinghorne, Faith, Science and Understanding, 20.

7 Sæther, Traces of God, 121.

8 John Polkinghorne, Science and Creation: The Search for Understanding (London: SPCK, 1988), 15.

9 See Niels Henrik Gregersen, "A Contextual Coherence Theory for the Science-Theology Dialogue", in Rethinking Theology and Science, ed. Niels Henrik Gregersen and J. Wentzel van Huyssteen (Grand Rapids: Wm. B. Eerdmans Publishing, 1998), 186.

10 See Polkinghorne Faith, Science and Understanding, 27.

11 For a discussion on critical realism, see such as Niels Henrik Gregersen, "Critical Realism and Other Realisms", in Robert John Russell ed., Fifty Years in Science and Religion: Ian G. Barbour and his Legacy, (Aldershot: Ashgate, 2004), 77-96, and Andreas Losch, "Critical Realism - A Sustainable Bridge Between Science and Religion?” Theology and Science, Vol. 8, No. 4, 2010, 393-416.

12 See such as Kees van Kooten Niekerk, "A Critical Realist Perspective on the Dialogue between Theology and Science", in Niels Henrik Gregersen and J. Wentzel van Huyssteen eds., Rethinking Theology and Science: Six Models for the Current Dialogue, (Grand Rapids: Wm. B. Eerdmans Publishing, 1998), 51-86. 13 See Ted Peters, "Science and Theology: Toward Consonance", in ed. Ted Peters Science and Theology: The New Consonance, (Boulder: Westview Press, 1998), 24.

14 See van Kooten Niekerk, "A Critical Realist Perspective on the Dialogue between Theology and Science”, 74.

15 See van Kooten Niekerk, "A Critical Realist Perspective on the Dialogue between Theology and Science”, 76.

16 Andreas Losch, "Our World is more than Physics: A Constructive - Critical Comment on the Current Science and Theology Debate”, Theology and Science, Vol. 3, No. 3, 2005, 281.

17 Losch, "Our World is more than Physics: A Constructive - Critical Comment on the Current Science and Theology Debate", 283.

18 Losch, "Our World is more than Physics, 283.

19 Losch, "Our World is more than Physics, 285.

20 See Losch, "Our World is more than Physics, 285.

21 See Robert Audi, Epistemology: A Contemporary Introduction to the Theory of Knowledge (New York: Routledge, 2003), 194; 210.

22 In the context of the science-religion dialogue, one of many critical scholars of foundationalism is Wentzel van Huyssteen. He says foundationalism is the claim that "our beliefs can be warranted or justified by appealing to some item of knowledge that is self-evident or beyond doubt..." - J. Wentzel van Huyssteen, Essays in Postfoundationalist Theology (Grand Rapids: W. B. Eerdmans Publishing Company, 1997), 226.

23 See Van Huyssteen, Essays in Postfoundationalist Theology and Gregersen, "A Contextual Coherence Theory for the Science-Theology Dialogue", 51-86. 
24 Gregersen, “A Contextual Coherence Theory”, 193.

25 John Polkinghorne, "Religion in an Age of Science", McNair Lecture Chapel Hill. UNC March 23, 1993.

26 Miroslav Volf and Matthew Croasmun, For the Life of the World: Theology That Makes a Difference (Brazos Press, 2019), 49.

27 On how the beauty of nature and other related experiences of nature (such as the sublime and wonder) can be explored along these lines, see Knut-Willy Sæther, "Aesthetics at the Intersection of Science and Theology", in Our Common Cosmos: Exploring the Future of Theology, Human Culture and Space Sciences, ed. Zoë Lehmann Imfeld and Andreas Losch (London: T\&T Clark, 2018), 109-124, esp. 114. 